\section{DO DESPORTO: NECESSIDADE DE RECORDAR E AVIVAR O SEU LEGADO}

Resumo - O desporto na sua simplicidade e, ao mesmo tempo, na sua complexidade perpassa por um amplo leque de conhecimentos como a filosofia (na ética e na estética), antropologia, a arte e poesia, o simbólico, o pedagógico e o holístico. O desporto, sendo assim, um elemento civilizador e universal, é uma invenção para promover a beleza e elevação do corpo, um espaço de criação e apresentação, de recepção e fruição de arte, quer como atleta, quer como espectador; uma sinfonia e maestria de gestos e atos com exigentes e elevados requisitos de plasticidade e estética.

Palavras-chave: Desporto; Ética; Estética.

\section{FROM SPORT: NEED TO REMEMBER AND ENLIVEN YOUR LEGACY}

Abstract - Sport in its simplicity and at the same time in its complexity permeates a wide range of knowledge such as philosophy (in ethics and aesthetics), anthropology, art and poetry, the symbolic, the pedagogical and the holistic. Sport, therefore, a civilizing and universal element, is an invention to promote the beauty and elevation of the body, a space of creation and presentation, reception and enjoyment of art, either as an athlete or as a spectator; a symphony and mastery of gestures and acts with demanding and high requirements of plasticity and aesthetics.

Keywords: Sport; Ethic; Aesthetics.

\section{DEL DEPORTE: NECESIDAD RECORDAR Y REVIVIR SU LEGADO}

Resumen - El deporte en su simplicidad y al mismo tiempo en su complejidad impregna una amplia gama de conocimientos como la filosofía (en ética y estética), antropología, arte y poesía, lo simbólico, lo pedagógico y lo holístico. El deporte, siendo así un elemento universal y civilizador, es una invención para promover la belleza y la elevación del cuerpo, un espacio para la creación y presentación, recepción y disfrute del arte, tanto como atleta como espectador; Una sinfonía y dominio de gestos y actos con exigentes y altos requisitos de plasticidad y estética.

Palabras-clave: Deporte; Ética; Estética. 
Bento JO. Do desporto: Necessidade de recordar e avivar seu legado. Olimpianos - Journal of Olympic Studies. 2019; 3: 1-26.

\section{Ementa de justificações e propósitos}

Caríssimos leitores:

A abordagem, que decidi elaborar, encontra justificação nesta citação de Oscar Wilde (1854-1900), poeta e dramaturgo irlandês, “O mundo pode ser um palco. Mas o elenco é um horror","

A ética foi a enterrar, sem choro nem velas; abundam as carpideiras para a chorar, mas escasseiam os messias de verdade, não fingidos ou pantomineiros, para a ressuscitar.

Assim, as considerações, expostas nestas linhas, equivalem a um pedido endereçado a todos os agentes do ensino, da prática e promoção do desporto. Espero que o acolham e lhe deem o melhor seguimento possível.

Peço-lhes que não cedam à tentação de esvaziar o desporto da sua substância, do que está sob a sua visibilidade superficial, do seu sentido mais profundo. Que cuidem da sua aparência, porque esta induz a essência. Que se abstenham de o apresentar como algo reprovável e detestável. E que cessem de inocular, nas crianças e jovens, atitudes de negativismo, de pessimismo e infelicidade. Semeiem neles a obrigação de ser felizes e solidários, o sonho de se realizar, de se cumprir e aperfeiçoar também na vivência deste fenómeno tão belo, tão humano.

Somos educadores. O nosso discurso tem que ser saudável e otimista, sabendo que é mais difícil criar do que destruir. Não somos carregadores de sombras, que fazem com que sempre seja noite e escuro dentro de nós. Obrigamo-nos a transportar e irradiar uma centelha que faça sol fora de nós. Temos a incumbência de clarear caminhos.

Constitui negação pedagógica olvidar aquilo que constitui o cerne do desporto, a sua razão de ser: cultivar a forma humana, o aprimoramento comportamental e gestual dos humanos, a arété, a estética, a ética, a virtude e excelsitude mediadas pela técnica.

Cumpre-nos, pois, enaltecer e valorizar o que o desporto configura:

- Harmonia de trabalho e jogo, do custoso e do prazeroso;

- Humanização e sublimação do labor esforçado e suado;

- Congregação e conjugação extraordinárias e ímpares de coisas que apenas são contraditórias na aparência.

\footnotetext{
*Ao longo do texto surgem várias citações, sem referir a fonte consoante os cânones estabelecidos para publicações académicas. Peço desculpa. Coletei as citações ao longo dos anos; e não cuidei de fazer isto com o devido rigor. Ademais, este escrito constitui um ensaio; não pretende ser um paper científico.
} 
Bento JO. Do desporto: Necessidade de recordar e avivar seu legado. Olimpianos - Journal of Olympic Studies. 2019; 3: 1-26.

Nesta conformidade venho recordar, isto é, tentar fazer com que passem pelo vosso coração e comandem os vossos passos, as coisas fantásticas que o desporto encerra. Para tanto sirvo-me do amparo antropológico e filosófico.

Obviamente, estou eivado de condicionamentos e limitações. Desde o início até ao termo das funções docentes na Universidade, nunca consegui ver e dimensionar o papel da educação, do desporto e de outros domínios culturais fora do âmbito de avaliação do seu contributo para a melhoria da pessoa e, consequentemente, da vida e do mundo. É por aí que começa e vai qualquer laboração teórica.

Hoje conservo, ainda mais reforçada, tal convicção. Considero falaciosas propostas não comprometidas com aquele desígnio. A axiologia, a ponderação dos princípios e fins, não pode deixar de presidir ao questionamento dos caminhos a seguir. Mesmo quando parece tratar-se apenas de questões e soluções técnicas.

É inaceitável numa argumentação séria e, portanto, indigno do ensino dito superior ignorar o teor filosófico dos assuntos. O particular obriga-se a buscar a largueza dos horizontes, a integrar o abrangente e transdisciplinar, para obviar que a especialização se torne bastião do dogma, rebaixe o nível da consciência e da razão, e leve ao concomitante estreitamento da liberdade.

Não sei soltar-me desse condicionamento e do quadro por ele traçado, nem pensar de outro jeito. Eis uma limitação, obviamente, pessoal!

Falemos a partir do Humanismo, dos ideais e valores inerentes à busca do sentido último da vida. Falemos a partir do entendimento da educação e formação, do desporto e da educação física, da escola e Universidade como laboratórios criadores de Luz Universal, como entidades preocupadas com a realização da Humanidade. Disponíveis para denunciar o aviltamento e descaso a que esta é sujeita.

Esta é uma hora de escuridão ética. Ainda não é o horror absoluto, mas o cenário do dia-a-dia e os palcos da Sociedade e da Humanidade já foram tomados por uma manifesta e trágica regressão civilizacional, pela banalidade da habituação à destruição de marcos paradigmáticos da civilização, aos crimes mais hediondos, perpetrados não na calada da noite, mas em pleno dia.

Quem lê as clarividentes análises de Zygmunt Bauman sobre a contemporaneidade líquida, fica obrigado a partilhar as ansiedades irradiadas pelo ilustre hermeneuta. 
Bento JO. Do desporto: Necessidade de recordar e avivar seu legado. Olimpianos - Journal of Olympic Studies. 2019; 3: 1-26.

Vivemos uma era crepuscular (Lipovetski). Ela parece apostada em:

- Destruir todos os legados, axiomas e marcos da Modernidade;

- Abater o que é sólido e as fontes e instituições fiadoras de confiança e segurança;

- Estabelecer o primado do líquido, do efémero, do superficial, do volátil;

- Explorar o capital da angústia, da incerteza, da insegurança, do desespero e do medo.

Vem a propósito citar uma passagem do livro Os Maias, de Eça de Queirós $(1845-1900)$

(...) Estou como tu dizias aqui há tempos: Caiu-me a alma a uma latrina, preciso de um banho por dentro!

Ega murmurou melancolicamente:

- Essa necessidade de banhos morais está-se tornando com efeito tão frequente!... Devia haver na cidade um estabelecimento para eles ${ }^{\dagger}$.

O panorama desolador aconselha uma viagem às fontes matriciais do desporto (arété, cultura e paideia gregas) e às luzes da sua renovação (Modernidade, Humanismo e Iluminismo). Ela revela-nos que ele nasceu e cresceu de uma aliança natural com fins, normativos, princípios, referenciais e símbolos axiológicos, éticos e estéticos.

Nesta conformidade vamos guiar-nos, neste nosso encontro, pelos seguintes objetivos:

- Recordar e revisitar a matriz artística do desporto;

- Apelar à urgência de remissão discursiva e prática do ideário desportivo;

- Advertir para desvios e perigos da mentalidade fabricadora e utilitária, de uma racionalidade tecnocrática, sem abertura para inquietudes éticas;

- Acordar a necessidade de renovar os olhares filosóficos e pedagógicos sobre o desporto;

- Desatar as energias interiores de cada um e fazer sonhar com novos céus e nova terra.

\footnotetext{
†Igualmente é oportuno citar Mia Couto (O último voo do flamingo), "Este mundo tem mais dentes do que bocas. É mais fácil morder do que beijar.”
} 
Bento JO. Do desporto: Necessidade de recordar e avivar seu legado. Olimpianos - Journal of Olympic Studies. 2019; 3: 1-26.

O alvo principal da minha intenção é o de chamar a vossa atenção para o facto de que o desporto (como espetáculo, nomeadamente o futebol) esquece, não raras vezes, a sua idiossincrasia; está a ser capturado pelo pragmatismo e utilitarismo, pelos tentáculos do polvo do mercado e pela civilização do espetáculo (Vargas Llosa), correndo o risco de se afastar do estádio grego e abeirar do circo romano, de se divorciar da arété e paideia gregas, da cultura humanista e iluminista.

O mesmo acontece na educação, inclusive na universidade, bem como no contexto sociocultural. Por isso o olhar sobre o desporto implica um olhar sobre a conjuntura, reprova a indiferença face ao que nela se oferece, toma partido. Ninguém fala a partir de um lugar neutro; todos falamos a partir de um lugar social, próprio e circunstancial.

\section{Desporto e Filosofar}

A meditação filosófica recomenda-se em todas as épocas e em todos os setores como maneira de gerir lucidamente a vida. Não há outra via para alcançar esta meta. Aquela assume carácter de urgência num tempo tão conturbado como o presente. No entanto e paradoxalmente, a filosofia vê-se hoje combatida e perseguida como um vírus, forçada a fugir das instâncias que comandam o nosso destino individual e coletivo. Porém não resta alternativa à de irmos atrás dela e à do seu incitamento para revisarmos a vida e as circunstâncias que a envolvem, condicionam e determinam.

Filosofar é questionar o que nos rodeia e perturba; é olhar para o alto, para fora e para além de nós, à procura de uma referência e de um ponto de apoio que permitam sobrepujar a realidade. Estamos assim a fazer uso da razão para nos pensarmos a nós mesmos e ao mundo em que vivemos com as suas crenças, manipulações, tradições, costumes e mitos. Quando, na nossa ação, não usamos a inteligência, a lucidez, a sensatez e a força da razão, então caímos nas garras do manicómio ideológico ou de outro matiz.

Filosofar é imaginar algo novo e superior, constituindo um exercício de autonomia e liberdade, próprio de quem não se acomoda e rende aos determinismos e alienações de toda a ordem.

Pensar e filosofar são atos corrosivos e subversivos dos poderes vigentes e da doutrina e realidade por eles estabelecidas; desacorrentam e desfazem nós, iluminam o 
Bento JO. Do desporto: Necessidade de recordar e avivar seu legado. Olimpianos - Journal of Olympic Studies. 2019; 3: 1-26.

caminho e a porta de saída das armadilhas e labirintos em que nos deixamos aprisionar. Mais ainda, pensamentos são já em si eventos, idealizam, antecipam e projetam a realização de ações. A um modo de pensar corresponde a adesão a uma maneira de agir.

É óbvio que a filosofia tem subjacentes a apetência, a curiosidade e a vontade de saber. Mas isso requer a percepção e o desconforto do vazio, a noção e a insatisfação da falta. E isto, por sua vez, pressupõe competência crítica e sabedoria para visionar a altura, para romper a rotina e o conformismo, para perceber as novas questões e maneiras de as abordar, para não nos contentarmos com um formato pequeno das coisas e factos da vida.

Viver é a nossa ocupação fundamental, logo a sabedoria tem como alvo a melhor gestão possível da vida. E para isso não há bula de garantias. Saber viver é o conhecimento mais difícil de adquirir; não há nada tão exigente, belo e sublime como desempenhar corretamente a existência e o papel da Pessoa que nela somos chamados a incarnar e representar.

Não obstante este desafio e apesar de fazer parte da nossa natureza intrínseca a possibilidade de nos pensarmos em profundidade e de questionarmos as relações com a crescente complexidade do mundo, a filosofia é encarada como algo estranho e distante, como um diletantismo sem préstimo. Damo-nos bem com a sujeição a um fabrico de identidades em série, a um mundo às avessas em que os interesses tomam o lugar dos princípios; reagimos pouco aos cenários traçados e impostos pelos politólogos e economistas e pelos comentadores de serviço.

Em todo o caso, a vacuidade e o abismo interiores, o tédio angustiante e a asfixiante ausência de um sentido para a vida não cessam de aumentar. Ou seja, é a conjuntura que pede para trazermos de volta a palavra da filosofia, sabendo que a voz da razão é baixa e débil, mas não descansa enquanto não tiver audiência bastante. Por isso neste tempo de neblina e cerração é preciso filosofar.

Pitágoras (570/571-496/497 a.C.), filósofo e matemático da Antiguidade grega, definiu a vida como uma feira. Uns vêm a ela para vender e outros para comprar, ao passo que outros ainda vêm para ver, para contemplar e observar quem e aquilo que se compra e vende. Vêm para apreciar e refletir sobre o comportamento humano e as regras do jogo de vivermos juntos. Sobre o modo de concretizar a Humanidade. 
Bento JO. Do desporto: Necessidade de recordar e avivar seu legado. Olimpianos - Journal of Olympic Studies. 2019; 3: 1-26.

Pitágoras não tinha dúvida de que os melhores são os que vêm à vida para reparar nos outros, para se preocupar com eles, para se lembrar deles, para ser solidários. E por isso classificou-os como seres quase perfeitos, quase felizes, quase divinos.

Sófocles (497/496-406/405 a.C.), uma outra figura insigne, autor de obrasprimas da tragédia grega, tais como Antígona, Electra e O Rei Édipo, quando perguntado por um discípulo acerca do castigo reservado aos que não filosofam, foi perentório na resposta: É a vida que levam! É serem o que são e não serem o que deviam e poderiam ser.

O mundo, que temos e vemos, mostra o que somos, isto é, a filosofia e a sabedoria de vida que nos faltam. A filosofia dominante é a da ausência de uma clara orientação filosófica; no lugar desta crescem o improviso e o deserto de causas, ideias e utopias. Alguns dizem gostar; não são eles quem fala, são a estultícia, a ignorância e pasmaceira que os habitam.

Ora, o labor desportivo não dispensa a autorreflexão, o dever de cada um tornar imanente a si mesmo, às suas convicções, ações e respetivas consequências uma teoria da transcendência. Uma teoria com um alcance e pensamento normativos alargados, que estipule o que deve ser, combata a arrogância, a sobranceria e o autoritarismo da estupidez; e convide a questionar os meios e os fins, a sacralizar o Outro, a divinizar o Humano, a tornar mais Humanas as coisas, a dar-se ao esforço de perseguir a beleza, a graça, a perfectibilidade e a liberdade, a sair e a distanciar-se de si, a adicionar às caraterísticas originais, particulares e situacionais excertos, noções e valores universais. Incorpora-se, assim, na individualidade e singularidade, a condição da universalidade, dada por uma perspectiva mais ampla, por uma experiência com selo e identificação de Humanidade.

Esta obrigação afigura-se óbvia para todos, nomeadamente para os que exercem o seu mister no desporto e se interrogam acerca das tortuosidades que ele está a adotar. Não é necessário ser filósofo por formação e profissão para assumir a indagação; ela impõe-se e é imanente e transversal a todos. A reflexão crítica é um imperativo moral de todo o ser humano digno desse nome, que não suspenda o interesse pelo mundo e queira estar à altura das circunstâncias, circundações e exigências da vida. 
Bento JO. Do desporto: Necessidade de recordar e avivar seu legado. Olimpianos - Journal of Olympic Studies. 2019; 3: 1-26.

Logo um professor ou treinador desportivo não pode deixar de exercitar essa qualidade indispensável à separação do trigo do joio, de procurar o apurado grau da capacidade de espírito crítico em relação a si mesmo, ao seu perfil, papel e labor; nem pode ficar neutro e indiferente ao modelo que hoje se quer impor a todo o custo, qual seja o de colocar a vida, a sociedade, a cultura e o desporto sob os ditames exclusivos do mercado e das suas ambições curtas, míopes, pequenas e comezinhas, rasteiras e torpes.

Ademais, um genuíno Ser Humano deve tender para se afastar da ignorância e incultura e abeirar da sabedoria; e esta, como dizia Hegel (1770-1831), "tem início com as ideias e termina com a imundície”, com a estreiteza das noções, visões e perspectivas.

Ou será que a um Professor de Educação Física e a um Treinador Desportivo basta uma especialização em miudezas, em coisas minúsculas, vazia de compreensão do todo, uma confrangedora penúria de inquietação em relação ao cru e gélido modelo neoliberal em que, pouco a pouco, mergulhamos? Não tem necessidade de alargar os horizontes da sua especialidade e de enxergar, para além deles, dimensões abrangentes, fundadoras e mais promissoras? Não carece de uma teoria que o habilite e impulsione a chegar ao Citius, Altius, Fortius, ao mais elevado e longe, ao superior e divino?

\section{Conceito de desporto}

O desporto não existe no singular. Requer ser entendido como fenómeno polissémico (pluralidade de sentidos) e realidade polimórfica (pluralidade de formas e modelos). O seu entendimento no plural desdobra-se em várias noções e implicações.

Ao desporto subjaz um conceito representativo, agregador, sintetizador e unificador de dimensões biológicas, físicas, motoras, lúdicas, corporais, técnicas e táticas, culturais, mentais, espirituais, psicológicas, sociais e afetivas.

$\mathrm{O}$ ato desportivo tem implícito tudo isso, sem o esgotar. Encerra um sentido abrangente e maior e não redutor como o das conhecidas expressões educação física, atividade física, motricidade, movimento humano ou outras afins.

O desporto é denominador comum da execução sublimada de capacidades, habilidades e potencialidades corporais transcendidas. Nele exibem-se os dois polos e valores antagónicos que respondem à dupla voz da nossa condição humana: a que se 
Bento JO. Do desporto: Necessidade de recordar e avivar seu legado. Olimpianos - Journal of Olympic Studies. 2019; 3: 1-26.

exprime em altura e a que se exprime em baixeza. Nele somos para além do que nos amarra à terra e ao corpo e assim tornamos este espírito incarnado.

A dimensão física, por exemplo, da corrida ou marcha, é muito menor do que a dimensão mental e volitiva. Só é física a face realizadora e visível. A dimensão maior é a da sua substância e intencionalidade, pertence à parte decisória e reflexiva. Ademais, uma atividade (escrever, lavrar, pintar, correr etc.), sendo física na forma da sua execução, não se define e designa em função desta, mas sim da intencionalidade que a preside, do efeito e performance que visa e alcança. É aqui que reside a sua fonte matricial.

Agucemos o olhar! O desporto promove o protocorpo biológico e motor a corpo cultural e simbólico, portador de sentidos para estruturar o viver. Participa na construção da alma, do que temos por dentro, e preenche os vazios da nossa interioridade.

É, como já se disse, um fator de implantação da desejada condição humana e social, de progresso sentimental, comportamental, gestual, ético, estético e moral. Civiliza a conduta corporal, ética e moral em relação a nós e aos outros.

Seja-me permitido um tom chocalheiro e, quiçá, jocoso, para evidenciar as diferenças do desporto em relação a termos introduzidos no vocabulário académico, tais como atividade física e motricidade humana.

Se nos dermos a comparações para o medir e avaliar, só aumentam as razões para nele acreditar; a todas as depreciações ele consegue ganhar.

Atividade física é acionismo natural; desporto é ato cultural. Ela é imanência da nossa condição; ele é prótese criada pela civilização. Ela é ditada pelo peso da excrescência; ele provém da noção de insuficiência. Desporto é algo mais e além; ela é algo menos e aquém. Nele moram a consciência da falta de forças e capacidades e a vontade da sua criação e exaltação; ela cinge à conformação, limitação e resignação. Ele aponta a lonjura e o cume da elevação; ela contenta-se com o umbigo e em olhar o chão. Nele enfrenta-se o vento e as marés; nela gasta-se o tempo e os pés. Ele quer fazer do corpo uma encarnação do espírito e inteligência; ela satisfaz-se em queimar gordura e aligeirar a indolência. Ele é marco civilizacional; ela é moda ocasional.

Ele ocupa-se da formação do carácter e do quanto este obriga; ela cuida do aspeto das pernas e do volume da barriga. Ele é beleza, paixão e encantamento; ela é 
Bento JO. Do desporto: Necessidade de recordar e avivar seu legado. Olimpianos - Journal of Olympic Studies. 2019; 3: 1-26.

penitência, obrigação e sofrimento. Ela é remédio e necessidade; ele é opção e exercício da liberdade. Ela pode diminuir a obesidade; ele gera riso e habilidade. Ele assume o risco com otimismo; ela segue a regra do conformismo. Ele visa o teto ilimitado e infinito; ela o gesto contido e restrito. Ele é comunicação, partilha e comunhão; ela cumpre-se no isolamento e solidão. Ele é impulso, orgasmo, êxtase e ousadia; ela é medicamento, bula de calorias e sensaborias. Ele é euforia e sublimação da vida; ela é expiação da culpa assumida. Ela é moda ocasional; ele é marco civilizacional. Ela é comum ao animal; ele é próprio do ser social.

\section{Desporto: Sublimação e espiritualização do corpo}

A civilização começou propriamente, quando os hominianos (expressão de Michel Serres) se colocaram duas questões fundamentais: O que é o Ser Humano? Qual é o sentido da vida?

Conforme o tipo de respostas dadas a estas interrogações, em diferentes tempos e locais, assim surgiram (e vão continuar a surgir) distintas formas de cultura, no plano geral, e de culturas somáticas ou corporais, no plano particular.

O desporto é uma dessas culturas somáticas; dá voz ao mandamento de que o ideal de Homem e o sentido da vida também se cumprem e têm que cumprir através de prestações corporais. Iluminado pelos mitos de Jápeto, Prometeu, Hércules e Odisseu, o desporto tem subjacente o axioma de que o corpo constitui um palco de sublimação, superação e transcendência do animal em direção ao humano e divino.

E o que é a transcendência? A transcendência é a dimensão religiosa de toda a cultura.

Quanto à cultura, ela é uma manifestação humana, de índole religiosa, que exprime ou intenta exprimir o que em nós há de melhor: a procura da fonte de sentido, o que podemos esperar da vida e o que podemos fazer uns pelos outros da forma mais autêntica, mais bela, mais elevada e excelente possível. Por isso a cultura encerra uma axiologia, uma ética e uma estética. É o caso do desporto.

\footnotetext{
"Sigmund Freud (1856-1939) viu o início da civilização no momento em que, pela primeira vez, o indivíduo hominiano prescindiu de atirar a flecha ou a lança e recorreu ao insulto e ameaça do semelhante, para o escorraçar do terreno de caça e coleta de alimentos. Esta substituição constitui um grande avanço civilizacional!
} 
Bento JO. Do desporto: Necessidade de recordar e avivar seu legado. Olimpianos - Journal of Olympic Studies. 2019; 3: 1-26.

Em suma, o desporto criado pelos gregos (e fecundado pelo fermento judaicocristão) tem na sua matriz a ânsia de transcendência. Cuida do orgânico, visando implantar nele o supra orgânico. Representa uma confrontação ou diálogo entre o real e o virtual. Participa no esforço de humanização e divinização do animal humano, no intento de criar e acrescentar dimensões sagradas às dimensões profanas, de produzir criaturas transcendentes e transcendidas pela arte e a cultura, quase divinas. Visa acrescentar e partilhar a Humanidade, evitar o seu encolhimento e diminuição.

\section{Desporto: Fenómeno antropológico, civilizador e universal}

Há mais! O desporto é um fenómeno antropológico, logo irrecusável. Configura uma síntese inigualável de categorias antropológicas essenciais e indispensáveis à vida: Corpo, exercitação, movimento, jogo, rendimento, ação e reflexão, emoção e razão, ócio e trabalho, dor e prazer, concentração e diversão, aflição e exaltação, derrota e vitória, abatimento e êxtase etc.

O desporto inclui o brincar, jogar e desfrutar, correspondendo a uma necessidade existencial. E é igualmente um fenómeno universal, surgido em toda a parte, investido de uma pluralidade de sentidos e concretizado numa pluralidade de formas e modelos.

Ele é mais do que uma brincadeira ou folguedo. Essencialmente pertence ao domínio do simbólico e artístico, da arte e da cultura: cumpre fins e preceitos axiológicos, educativos, humanistas, sociais e morais. Serve o processo civilizador, institui e melhora o índice de civilização: a autoimposição de controlos, de freios e inibições. O que nele é proibido supera, de longe, o que é permitido. No seu ensino e prática almeja-se dominar e sublimar o animal astuto e rastejante, sempre à espreita de uma oportunidade para se rebelar.

A aprendizagem das habilidades e a observância das regras inscrevem-se nesta visão. São instrumentais da ética e da estética, do comportamento gestual e relacional, da sociabilidade presencial, hoje amarfanhada pela virtual. $\mathrm{O}$ aprimoramento técnico dos gestos e ações opõe-se à brutalidade, à rudeza e violência latentes em nós. Eis aqui a missão cimeira do desporto e dos seus professores!

Procedamos a outros acrescentos, trazendo à colação a vertente da criação!

$\mathrm{O}$ relativismo tem que ser combatido em todas as frentes, porque, sem atividade criadora e transcendente, não há liberdade nem independência. Também ataca no 
Bento JO. Do desporto: Necessidade de recordar e avivar seu legado. Olimpianos - Journal of Olympic Studies. 2019; 3: 1-26.

desporto. Temos que lhe cortar o passo e barrar o caminho. Sem rendimentos elevados e performances excecionais, o desporto perderia a exemplaridade e fulgurância cultural.

Só derrotaremos o relativismo no desporto, se este continuar a ser um campo de florescimento e frutificação do génio e engenho humanos.

Vejamos o desporto como um repositório de tecnologias corporais, sendo o uso destas balizado por razões e padrões culturais e por metas, intencionalidades e valorizações sociais. À luz deste entendimento adiciono três noções que ilustram o posicionamento no tocante ao assunto aqui em apreço.

Em primeiro lugar, cada modalidade desportiva problematiza e edifica o corpo à sua maneira, estabelece com ele um relacionamento ditado pelas regras e estrutura das exigências e rendimentos inscritos nas ações. Em cada uma delas emerge uma versão de corpo, concordante com os ditames de funcionalidade, de economia, de estética ou outros em causa. O corpo do voleibolista é outro que não o do futebolista, do ginasta ou do maratonista, por exemplo.

Como se percebe, a lógica da função preside à construção corporal; é ela que orienta os esforços do construtor e certifica a garantia do modelo alcançado.

Em segundo lugar, o uso desportivo do corpo pode ser instrumentalizado para distintas e até contraditórias finalidades, em consonância com a vigência, a dinâmica e a mutabilidade dos conceitos culturais e dos problemas e necessidades sociais ${ }^{\S}$.

Em terceiro lugar, aquilo que o desporto trata, constitui o seu fundamento e escapa à compreensão de muitos olhares: é a forma humana, o aprimoramento corporal, gestual e comportamental do homem! É desígnio do desporto servir esse projeto inconcluso e inacabado que, desde o início e até ao fim dos tempos, move e há de continuar a mover a civilização: A arété dos gregos, que converge para a ação correta, para a arte, para a felicidade e a salvação da vida.

Como definir então o desporto? As definições, sendo tantas e inesgotáveis, podem ser sintetizadas deste jeito:

- Meio de dobrar o portal de entrada na Humanidade;

- Instrumento de Anagogia e Demopedia, de elevação do indivíduo e de melhoria dos povos;

${ }^{\S}$ Os diferentes modelos de deporto expressam a diversidade de finalidades e instrumentalizações que servem: alto rendimento, educação, condição física e saúde, inclusão, recreação, reabilitação, etc. 
Bento JO. Do desporto: Necessidade de recordar e avivar seu legado. Olimpianos - Journal of Olympic Studies. 2019; 3: 1-26.

- Construção pedagógica para o sentido da vida.

Ademais, o desporto é um território de fronteira:

- Entre vários olhares;

- Entre vários conhecimentos e disciplinas científicas;

- Entre diversas finalidades e instrumentalizações.

\section{Desporto: Harmonia do corpo e da mente}

Enquanto não nos tornarmos pós-humanos, vivemos sob um aparato corporal, tal e qual como a tartaruga sob a carapaça. O desporto modela e reveste-nos de uma maneira única. Perfaz uma estrutura funcional de potencialidades biopsíquicas, genéticas, motoras, racionais, técnicas e relacionais. Conjuga-as e desenvolve-as na execução sublimada de capacidades e habilidades corporais transcendidas. Deste jeito o corpo sobe até onde lhe é possível, atingindo desempenhos transbiológicos, situados acima dos imperativos quotidianos.

No desporto a mente e o corpo atingem um estado de frutífera imbricação, intimidade e cumplicidade. Para marcar um golo nem o corpo basta nem o espírito chega; ambos são necessários em igual medida e perfeita harmonia. Ambos, o corpo e a ideia, casam-se e misturam-se para revelar e celebrar a maravilha exaltante da humana competência.

O ato desportivo só é físico na aparência da sua execução; é essencialmente um ato espiritual, anímico e volitivo! Nele as mãos e os pés tentam realizar por fora aquilo que primeiro foi idealizado e feito por dentro, pela alma e reflexão, pelo coração, pela razão e vontade. Encerra, pois, um sentido abrangente e superior. Sobreleva o significado redutor das expressões atividade física, motricidade, movimento humano e doutras afins. Para ver isto são necessários olhos munidos de acuradas lentes da filosofia.

\section{Desporto e liberdade transcendental}

Uma das marcas do indivíduo hominiano é a atração ou inclinação para o excessivo. Ele é o único dos animais com tendência para cometer excessos, para transgredir e violar o natural, para ter uma relação com o não vivível e usar uma fala suscetível de namorar e dizer o não dizível. Excede-se, desafia, investe e vai acima e 
Bento JO. Do desporto: Necessidade de recordar e avivar seu legado. Olimpianos - Journal of Olympic Studies. 2019; 3: 1-26.

além dos limites, em todas as dimensões, convertendo as potencialidades naturais em manifestações culturais, assim se artificializando e adicionando qualidades artificiais, geradas pela arte.

Afetado pela hibridez, ele tanto pode ser refém do feio e do mal como optar pelo bem e o bom. Esta possibilidade de opção faz dele um sujeito ético, metafísico, sobrenatural e místico, capaz de se afastar da esfera dos atos meramente utilitários. Um sujeito auto transcendente e problematizador, disponível para a transgressão, para sair de si e da subjetividade, para buscar e apropriar o não familiar e o não existente, distendendo-se num campo superior ao da objetividade e do estado dado. Somente seguindo esta via, é que se realiza como ser ético e estético, questionador, superador e transgressor do espaço do seu mundo estreito e fechado, visando contactar com o intocável.

É precisamente este o cerne da filosofia e da arte; e constitui o fim primeiro do desporto e nele é assaz visível, tal como em todas as modalidades da cultura e ciência.

Filosofia, arte e desporto são uma forma de procura e afirmação da verdade ética e estética, da virtualidade pura. Estas ganham foros de realidade no momento em que se toca o impossível. Dito de outro modo, a filosofia, a arte e o desporto são formas e instrumentos de realização de verdades não pré-existentes, de as inventar e produzir.

Ao convidarem, intimarem e pressionarem o artista a ir além da condição atual, a lançar-se e perder-se no espaço do indeterminado, a aprimorar, depurar e sublimar a forma, concitam para a verdade, ou seja, para o que sobra, o que resulta do excesso laborioso do artífice. É, assim, que o sujeito sai da restrita subjetividade, toma como objeto a edificação da sua identidade; e encontra-a na peregrinação atrás do impossível e incrível. A figura lendária e mítica de Ícaro só existe por ele ter arriscado voar e expor aos raios e ao calor do sol as asas fixas com cera.

Filosofia, arte e desporto estão ligados à liberdade transcendental, à transcendência fundamental e fundadora da pessoa. Cumprem a ofício de aguilhoar, desassossegar, instigar e remover o sujeito da mera circunstância, a abeirá-lo do supra subjetivo, do esplendor da verdade, do belo e do bom.

O desporto configura uma compilação de medidas e padrões de criação, estimulação e aferição da vontade, da coragem, da liberdade e do anticonformismo do 
Bento JO. Do desporto: Necessidade de recordar e avivar seu legado. Olimpianos - Journal of Olympic Studies. 2019; 3: 1-26.

sujeito. Para transgredir a ordem estabelecida, não se acomodar e conformar à autoimagem, para ativar o seu outro Ser e responsabilizar por essa ousadia.

Nele afirmam-se, ao mesmo tempo, uma forma de verdade e uma forma de vida, que partilha com os outros. Por isso, ele é, cumulativa e essencialmente, um campo de cultivo da alteridade, da convivialidade e solidariedade, de aprendizagem de normas do trato humano do outro, de apreço e assunção de responsabilidade pelo outro.

\section{Desporto: Arte performativa}

Nascemos e somos hominianos. Para evoluirmos para humanos temos que passar de seres biologicamente determinados a seres socioculturalmente configurados. Tal como postulou Friedrich Schiller (1759-1805), “a Arte é a mão direita da Natureza. Esta última deu-nos apenas o ser, a primeira fez de nós homens".

O desporto, como a cultura e a educação, surge a partir da noção e da consciência da necessidade de a diminuir ou suprimir a falta. Somos seres de falta e precariedade; são estas que indicam o caminho e nos segredam a construção de escadas que levem o limo da terra a escalar os céus, a subir na via da excelência e abeirar-se do Olimpo.

A incompletude e a imperfeição são a maior riqueza dos humanos. Nisso somos assaz abastados; essa mina contém um filão inesgotável, por mais intensiva e extensiva que seja a sua exploração.

Dito de outro modo "O homem é Homem através dos homens; só Deus é Deus através de Si mesmo". Assim prescreve um ditado dos Cabilas, tribo da Argélia. Realizamos a Humanidade através de feitos e proezas, da nossa autoria e da dos nossos semelhantes.

Aristóteles (384-322 a.C.) foi taxativo "Deus é demasiado perfeito para poder pensar noutra coisa senão em si próprio". Somos nós que devemos pensar e cuidar da nossa forma e condição, beleza e perfeição. Somos os arquitetos e obreiros do oitavo dia da criação. Chegou a nossa vez da criação: da nossa e do mundo!

Miguel Torga (1907-1995), em jeito de pergunta, coloca a responsabilidade nos nossos ombros, "A que deus implorar qualquer ajuda, se sou eu que fabrico as divindades?" 
Bento JO. Do desporto: Necessidade de recordar e avivar seu legado. Olimpianos - Journal of Olympic Studies. 2019; 3: 1-26.

Somente contamos conosco; ninguém mais vem em nosso auxílio. Somos os projetistas e construtores da obra humana. Partimos do que é carente, defeituoso, fraco, precário, insuficiente e incompleto. Há que procurar a completude sem repouso. Porque ela nunca se encontra, a arte da educação tem que continuar, "Assim - conclui Vergílio Ferreira (1916-1998) - o artista é maior do que Deus".

A fealdade desta hora manda retomar a visão do desporto como palco da estética, elaborar ensaios e estudos destinados a estabelecer padrões pedagógicos e didáticos, orientadores dos processos de ensino, aprendizagem e treino desportivos. Trata-se de recuperar uma herança assaz valiosa; de ir atrás, apreender e trazer para o presente o papel da técnica (techné grega) na estruturação do Humano. E a importância outorgada ao desporto para a consecução desta finalidade.

Para ser humano, afirmar, exibir, conservar e cultivar a Humanidade temos que fintar e contraditar o selo da origem animal. Temos que esculpir sonhos, por mais frágeis e leves que sejam, na madeira resistente e teimosa da nossa carne.

A consumação deste desiderato exige capacidade de criar, incorporar e consumir arte. O corpo ágil, apolíneo, belo, estético é um artefacto, um corpo moldado pela arte. O ser atleta transporta esse imaginário, desde a antiguidade até hoje.

O desporto cumpre uma função artística ao serviço da instituição da Humanidade, da dignidade e liberdade dos humanos. É uma arte performativa de quem o pratica e observa, uma coreografia de prestações, de gestos, movimentos e atos permeados por índices acentuados de espiritualidade, estética, plasticidade e beleza.

Huizinga (1872-1945) - in Homo Ludens - e Caillois (1913-1978) - in Les jeux et les hommes - evidenciaram a relação do jogo e desporto com a cultura, apresentandoos como uma maneira de reinterpretação da trama da vida e do mundo. E como método de tecer o Homem, de elevar as nossas aptidões e qualidades enquanto corporeidade.

Michel Serres apura-nos a compreensão. A consciência, tal como a alma, mora "nas singularidades contingentes, onde o corpo a tangencia". Assim

Os ginastas educam sua alma para se moverem ou se enrolarem em torno dela. (...) A barra fixa, o salto mortal, as argolas, o exercício no solo, o trampolim, os mergulhos valem por exercícios de metafísica experimental, como a passagem pela pequena vigia onde o corpo sai à procura da sua alma, onde ambos brincam, como os amantes, de se 
Bento JO. Do desporto: Necessidade de recordar e avivar seu legado. Olimpianos - Journal of Olympic Studies. 2019; 3: 1-26.

perderem e se acharem, às vezes de se separarem, para depois se juntarem, no risco e no prazer. Em certos jogos coletivos, os jogadores perderam sua alma porque a confiaram todos a um objeto comum, a bola: organizam-se, equilibram-se, enrolam-se em torno dela que vira coletiva.

O mesmo é dizer que "o corpo, localmente, joga bola com a alma" e que "a ginástica inaugura e condiciona a metafísica ${ }^{* *}$.

$\mathrm{Na}$ oficina desportiva o material usado é a dialética do que somos e ansiamos ser. Somos e provimos da culpa, da necessidade de esforço, suor e trabalho copiosos e incessantes. Ao lograr dobrar um pouco a nossa natureza começa essa coisa, que é bonita e se chama "condição humana".

É deveras difícil elogiar o desporto, por não ser fácil descrever a beleza e imagética que o perfazem e nos oferecem momentos de contacto intermitente com o fascínio das utopias da felicidade e verdade. Por se exibirem nele reações ruins e insanas. Mas isso não pode desviar o nosso olhar do seu apelo central: a insularidade e a autonomia da experiência estética em relação ao quotidiano, driblado e posto de lado durante a execução desportiva. Esta somente possui o singular poder de evocar e inundar a nossa alma de todos os sentimentos possíveis e conteúdos vitais. Nisto reside algo muito valioso que confere ao desporto o estatuto de arte.

Kant (1724-1804) proclamou que a arte é bela, quando parece ser natureza. Esta asserção aplica-se inteiramente ao desporto. Uma jogada ou um gesto são belos por nos parecerem atitudes naturais dos seus autores. Mais, o desporto congrega o belo e o feérico, a qualidade e a grandeza, a forma que limita o objeto e a ilimitabilidade que nele se vislumbra, aquilo que, ao mesmo tempo, nos aprimora e sobrepuja.

Poderá contrapor-se que isto se descortina e vivencia noutros objetos. Mas não com a intensidade torrencial, registada no desporto. Não há nada mais intenso do que assistir a um espetáculo desportivo, suportar a incerteza, esperar o que vai suceder, sem ter a garantia de que suceda, por ficar acima dos limites de previsão da prestação humana.

${ }^{* *}$ Serres M. Os cinco sentidos - Filosofia dos corpos misturados. Rio de Janeiro: Bertrand; 2001. 
Bento JO. Do desporto: Necessidade de recordar e avivar seu legado. Olimpianos - Journal of Olympic Studies. 2019; 3: 1-26.

O mesmo é dizer, a vivência estética usufruída no desporto, como praticantes ou como expectadores, sendo idêntica à da experiência estética em geral, distingue-se pelo facto de a nossa condição atuar perto do limite máximo. Oscilamos entre o aparecimento e a dissolução rápida e irreversível de formas magníficas de transfiguração corporal, entre a percepção da beleza na sua representação física e a obrigação de a interpretar conforme as regras em presença.

É isto que torna viciante o efeito estético do desporto; e torna este uma capela de epifanias e dramas. Tudo nele é real, nada é mera representação ou fingimento. Ele enleia-nos com o encanto das adaptações dos corpos a uma multiplicidade de formas e desempenhos, resultantes da conjugação do esforço com a dinâmica e o ritmo, com o rigor apolíneo e o excesso dionisíaco. Repare-se, por exemplo, na volta triunfal do atleta, de braços erguidos, que acaba de ganhar uma prova no estádio olímpico! Ele concita aplauso e respeito por ser a imagem entusiasmante e fulgurante de um sábio que dobrou o destino com a administração harmoniosa e inteligente das suas forças.

Nem toda a gente é capaz de ver estas coisas. Os indivíduos creem na existência do belo, muitos pressentem e lobrigam a sua presença aqui e ali, mas poucos sabem defini-lo. Ora, no desporto a arte, a beleza, a cultura, a ética e a estética oferecem-se, de graça, à contemplação de todos, mesmo dos que não sabem definir, conceitualizar e descrevê-las. O estádio é lugar da experiência arrebatadora; nele jorram rios de alegria, euforia, ansiedade, choro, drama, dor e tristeza que impedem a desidratação da sensibilidade.

\section{Desporto e poesia}

Talvez cause estranheza a associação do desporto e da poesia, por serem dois modos de expressão assaz distintos. Porém perseguem a mesma finalidade: alargar os limites da sensibilidade e arrancar do nosso íntimo - e até do nada - sentimentos e aspirações que se materializam em atos, sejam estes palavras ou gestos. Na poesia e no desporto caminha-se para a criação e a formação, a exaltação e a harmonia, a liberdade e a magnificência da alma e do corpo. Esgota-se o campo do possível e reduz-se o impossível ao nada, com a ajuda e posse de uma dada tecnicidade.

Ser poeta não é só escrever poemas; é descobrir e propor novas maneiras de viver. O mesmo faz o desportista. Bem vistas as coisas, poetas e desportistas são 
Bento JO. Do desporto: Necessidade de recordar e avivar seu legado. Olimpianos - Journal of Olympic Studies. 2019; 3: 1-26.

românticos. Por causa disso não têm vida fácil; sofrem as dores próprias e as alheias, tornando a existência ainda mais difícil do que é. Creio até que nos roubam a ilusão de que a vida pode ser feliz; ou então sugerem-nos que a felicidade se atinge pela via da maceração e renúncia, da sujeição a exigências e normas desafiantes do apuramento do estilo e do Ser. Que talvez assim expulsemos da existência as hidras e serpentes, os medos e traumas, os apertos e traições que nos amargam o dia-a-dia. Porventura ainda, é através desta purga que o corpo e a alma ficam livres e soltos para levantar voo para outra galáxia, para outra consciência, para outra forma e altura. Porque a modalidade de dizer e fazer rege-se pela medida da vida escolhida; e é esta que determina e habita quem a diz e configura.

No fundo, poesia e desporto são expressão exemplar de uma dialética de contrários, do descontentamento e contentamento, do espartano e hedonista; um aviso de que é ilusório tentar chegar à plenitude e autenticidade da vida, sem ser pelo caminho da observância de obrigações, princípios e ideais ${ }^{\dagger \dagger}$.

Eis nisto confirmada a convergência da poesia e do desporto, de dois tipos de ação aparentemente tão diferentes, mas afinal tão sintonizados um com o outro. $\mathrm{O}$ mito é o mesmo, o agonismo preside a ambos, a coroa de louros tem o mesmo preço, ambos comem o mesmo pão, bebem da mesma taça e saboreiam o mesmo vinho - e também o mesmo fel e vinagre. No papel abúlico e passivo - que se coloca à disposição da caneta - e no corpo dócil e plástico - que se submete aos métodos da exercitação, treino e competição - ficam impressos devaneios, ousadias e arrebatamentos da imaginação e ordens da vontade. Como manifestações e sequelas da vida que a cada um, poeta e desportista, toca viver.

O desporto e a poesia convidam-nos a olhar para dentro, a conhecermo-nos e a pôr termo à hipocrisia e ao descaso que levam à desumanização. Ambos surgem, de mãos dadas, aos meus olhos quase cansados e quase felizes e purificados, de tanto procurar e esperar que a paixão perdure e a felicidade aconteça.

\section{Desporto: um ato simbólico}

Vivemos num universo simbólico e não num contexto físico. Somos seres de distantes (noção helénica) e protagonistas de atos intencionados, interpretativos e

†Fernando Pessoa define-nos como seres descontentes. O que somos já não nos satisfaz; o estado alcançado intima-nos a tentar ser o que não somos, a buscar o que idealizamos e ainda não atingimos. 
Bento JO. Do desporto: Necessidade de recordar e avivar seu legado. Olimpianos - Journal of Olympic Studies. 2019; 3: 1-26.

instituidores de parâmetros e sentidos. Operamos não de um modo meramente instintivo ou reflexo, mas intencional. Confrontamo-nos com a natureza e a realidade, tendo símbolos por intermediários. Eles são significantes tanto para os praticantes de um ato como para os que o observam; codificam, organizam e regulam a conduta de uns em relação aos outros.

Partimos do não humano; é, com atos simbólicos e símbolos práticos, que nos definimos e auto programamos como humanos e desprogramamos como animais, subtraindo continuamente deficiências e acrescentando qualidades, alargando a disponibilidade para encarar o inacabamento, a inconclusão, a busca de perfeição.

Enquanto o animal vive sem propósito, os humanos propõem-se interpretações, noções, projetos e planos de vida, inscritos em atos e símbolos reveladores da sua liberdade, do que são e escolhem fazer, conjugando adequadamente os alvos e os meios, as causas e motivos, as razões, sentidos e instrumentos da intervenção no campo do real e possível.

Estes traços distintivos levam os humanos a antecipar o futuro e a perguntar o que fazer com o presente e os seus atos, para saírem do mundo do efémero e almejarem alcançar um estado, se não de eternidade, pelo menos de uma certa perenidade conferida pela dignidade e heroicidade dos feitos e pela glória deles decorrente, assim se divinizando e assemelhando aos deuses.

É nisto que se funda o desporto, uma metáfora da coragem e liberdade de escolher. Nele também se cuida da saúde e 'condição física'; mas vai-se mais longe. “Atuar", lembra Fernando Savater, "não é só pôr-se em movimento para satisfazer um instinto, mas levar a cabo um projecto que transcende o instintivo até o tornar irreconhecível ou suprir a sua carência ${ }^{\sharp "}$.

Não preparamos a comida só para nos alimentarmos, mas para desenvolver e estimular a sensibilidade gustativa, dando assim à culinária um estatuto de cultura e arte. Também não fazemos desporto só para nos mexermos, mas para darmos aos nossos movimentos e sentimentos uma roupagem artística. E para celebrarmos a festa da vida.

\# Savate F. A coragem de escolher. Lisboa: Publicações Dom Quixote; 2003. 
Bento JO. Do desporto: Necessidade de recordar e avivar seu legado. Olimpianos - Journal of Olympic Studies. 2019; 3: 1-26.

\section{Ensino da ética e da estética}

"A ética e a estética não se ensinam", oiço o grito ressoar estridente nos ouvidos. Alto aí! Ensinam, sim, por via indireta (e até direta). Como sei que o leitor é casmurro e insiste em contestar, vou dar-lhe uma aula professoral. Quanto mais não seja, ela serve para demonstrar que a jubilação não me afasta das lides conceptuais e mesmo didáticas.

Venha daí, e faça o favor de seguir os meus passos e indicações! Pegue numa bola de andebol ou de basquetebol ou de futebol; entregue-a a um bando de crianças. Repare que disse bando e não grupo; foi de propósito! Como é a cena que se desenrola aos seus olhos? Os membros do bando engalfinham-se uns nos outros; os mais fortes agarram e empurram os restantes, tentando assenhorear-se da bola. Um espetáculo perfeito de caos, desordem e incivilidade!

Qual é a sua reação, caro leitor, se isto o incomoda e deseja modificar o quadro? Não tem alternativa à de ensinar os gestos e as regras básicas do jogo. Pouco a pouco, à medida que os elementos estruturantes do jogo vão sendo aprendidos, a conduta das crianças altera-se, os instintos do bando convertem-se em comportamentos do grupo. Os agarrões e atropelos dão lugar a atos tecnicamente melhorados. As relações dos sujeitos entre si são ordenadas pelas operações inscritas no jogo. Ou seja, a apropriação da técnica amanha o terreno para o florescimento da ética e da estética. Os alunos libertamse de insuficiências primárias, das quais estavam totalmente dependentes; enraízam e alargam, assim, a capacidade de autonomia, de liberdade e escolha das suas atitudes.

Ensinar um jogo desportivo consiste precisamente nisto: ensinar ética e estética, por meio da transmissão e aquisição da técnica e das normas, sem necessidade de as nomear. Este ensino não é fácil, mas é profundamente exaltante e gratificante do ofício de um professor a sério. Os frutos ficam bem à vista: o praticante tecnicamente evoluído não recorre à falta e grosseria, é atraído e admirado pela busca e exibição do belo e sublime.

O desporto é, afinal, laboratório da Humanidade carente, frágil, imperfeita, incompleta, periclitante e precária: nele buscamos muito mais o que nos falta do que celebramos o que em nós abunda, visando melhorar o que somos e temos.

Estamos entendidos? O leitor apreendeu o subido alcance desta lição? Então vamos pô-lo em prática! Em nome da Cidade e Humanidade: do direito de todos a espaço e objeto. 
Bento JO. Do desporto: Necessidade de recordar e avivar seu legado. Olimpianos - Journal of Olympic Studies. 2019; 3: 1-26.

\section{Treinar: Categoria existencial}

Sou feito de barro quebradiço, dos pés até à cabeça; por mais que apalpe a carne e lance o olhar para dentro de mim, não logro encontrar sinais de genialidade. Não raras vezes, faço figura de paspalho. Em tempos, perguntei a um ilustre amigo como é que o coral, por ele regido, atingia um tão elevado nível de desempenho. Mal acabei de soltar a pergunta, percebi logo que me tinha espalhado a todo o comprimento.

O meu amigo voltou-se para mim e, com um ar misto de bonomia, de incredulidade e censura, lançou-me esta resposta fulminante, "Parece impossível como é que uma pessoa como tu, ligada ao desporto, formula uma pergunta destas! Conheces outra maneira de almejar a perfeição, a não ser o treino?!"

O sopapo acertou-me em cheio e atirou a minha reputação para a lama. Bem feito! Quem é que me dispensou de utilizar o cérebro e os neurónios, e mandou fazer perguntas disparatadas, próprias de um refinado idiota?!

Pois é, não há outro meio para nos aperfeiçoarmos e melhorarmos o nosso mister: treinar, exercitar, repetir, corrigir, tentar de novo, colocando a fasquia sempre mais alta, errar de novo, errar melhor.

É assim em tudo o que tem valor: na escrita e na literatura, na música e no canto, na ciência e na oratória, na escultura e pintura, na aprendizagem de uma língua e de fórmulas da álgebra ou da química, na adaptação a um ambiente estranho, para lecionar, palestrar e pensar, para praticar cirurgia com proficiência, etc. Tal e qual como no desporto! O treino é categoria existencial, fundamental para o agir exultante.

Treinamos para executar ideias, projetos e anseios que excedem a nossa medida e nos dão outra superior. Para acrescentarmos algo a nós mesmos e às influências que recebemos dos outros. Treinar é o querer transformado em ato, é converter o rascunho em texto, a intenção em obra, as fraquezas em forças, as potencialidades em qualidades, é dar beleza, expressão, forma, harmonia, ritmo, sentido e unidade ao disforme, disperso, inexpressivo e desordenado, é procurar realizar o Ser, que nos habita e insufla. Um veículo que nos leva para além do que somos e abeira do que vale a pena ser.

Sem dominar os elementos estruturantes de uma ação, é impossível que a criatividade surja e levante voo para a altura do espanto e da fruição. Não se cria a partir do nada; só a partir da sólida mestria do que já existe. Pablo Picasso, se não dominasse, em alto grau, as técnicas basilares da arte de pintar, não teria atingido a simplicidade, a 
Bento JO. Do desporto: Necessidade de recordar e avivar seu legado. Olimpianos - Journal of Olympic Studies. 2019; 3: 1-26.

sublimidade e expressividade nos seus quadros (p. ex., Guernica). Para isso teve que treinar muito!

Treinar é um "excesso" para depurar e eliminar o defeituoso e feio, o excessivo e oneroso, e tornar significativo o insignificante, algo muito exigente, difícil, incómodo e enfadonho. E até desanimador, porque a arte mora nos detalhes, e estes não se deixam aprimorar com um estalar de dedos ou com golpes de magia. Treinar é trabalho árduo e porfiado; custa sangue, suor e lágrimas. Mas, não dispomos de outra via para chegar à plena realização e satisfação, fazendo fé nas palavras de Fernando Pessoa

\footnotetext{
Quem quer passar além do Bojador

Tem que passar além da dor.

Deus ao mar o perigo e o abismo deu,

Mas nele é que espelhou o céu.
}

\section{Conclusão: Mensagens do desporto}

Em síntese, o desporto é uma invenção para promover a beleza e elevação do corpo, um espaço de criação e apresentação, de recepção e fruição de arte, quer como atleta, quer como espectador; uma sinfonia e maestria de gestos e atos com exigentes e elevados requisitos de plasticidade e estética. Uma arte performativa da leveza. Custa muito trabalho e ao mesmo tempo não o é, por ser ludismo e júbilo.

É um expediente da obrigação de criar espanto e surpresa, de levar o Belo, a alegria, o entusiasmo e o otimismo pela vida fora. Um estilo de viver colorido, festivo, intenso e quente; e, portanto, uma recusa da feieza imanente à escuridão do pessimismo e à vil e gélida tristeza do abandono, do isolamento e da solidão. É para isso que serve o "desporto para todos" (crianças, adultos e idosos, mais ou menos normais ou portadores de insuficiências): para que cada um, à sua maneira e medida, não deixe de se entender e coabitar com a chama, a elegância, a levidade e a beleza do jogo e da vida, para que experimente, granjeie e acumule contingências, instantes, factos e acontecimentos de assombro, estética e felicidade.

O desporto é uma liturgia de objetores da rendição à morte antecipada, uma ágora da luta pelo dia sem noite, um poema do desejo de não ficarmos retidos na cruz do abismo e do tédio, uma diáspora atrás da renovação e ressurreição contínuas. 
Bento JO. Do desporto: Necessidade de recordar e avivar seu legado. Olimpianos - Journal of Olympic Studies. 2019; 3: 1-26.

Adiciona à matriz helénica a esperança judaico-cristã; transfigura a tragédia grega por meio da excelência e distinção dos atos e feitos corporais, sublimando a dor e o seu poder de nos subjugar e destruir. Com a promessa de saúde e longevidade sustenta o sonho de um final feliz e assim o esforço é clarividente e iluminado pelo sorriso.

Como todas as formas de criação nas letras, nas artes, na ciência etc., o desporto é um dos palcos da competição humana onde se revelam contradições e avanços. Um artífice de melhoria da condição humana individual e universal. Um dos fatores de exaltação da Humanidade e da sua prometeica competência em canalizar as forças rasteiras da nossa natureza para alturas que nos redimem e maravilham. O campeão desportivo e os galardoados com o Prémio Nobel enfileiram neste património.

Este jogo celebra o poder do homem e da sua corporeidade em criar beleza, harmonia, perfeição e arte. Desafia e expande a plasticidade e a liberdade do corpo e a superação dos seus limites. Depura e civiliza o protocorpo natural, instala e aprimora o corpo cultural. E assim o empenhamento desportivo-corporal inscreve-se no objetivo de aperfeiçoamento estético da conduta geral do Homem.

Ao desenvencilhar-nos dos constrangimentos de um corpo inculto, inábil, grotesco e bruto, afirma-se como uma das instituições formais da condição humana. Ademais, à configuração dos ossos, músculos e articulações liga-se a edificação da consciência e vontade. Os atos desportivos são espirituais e anímicos; são sempre decisões volitivas, uma terapia da vontade para buscar o que nos falta ou conservar o que temos.

Mas... o que aprendemos realmente no desporto? Bem, ao ele está associada uma enciclopédia de valores e virtudes. Não vejo mal nisso, mesmo que se trate de ideações propensas a iluminar o belo e a esconder o feio.

Com e no desporto aprendemos muitas coisas positivas, que não sei formular de modo abrangente e clarividente. No mínimo, aprendemos a perder e ganhar cada vez melhor, até chegar a ser brilhantemente. Isto para mim é bastante e constitui um guião para a educação. Professores e treinadores devem privilegiar esta aprendizagem. Ah, como o mundo seria ridente, se fosse tingido pela amabilidade luminescente entre quem ganha e perde! Todos seriam vencedores e não haveria perdedores.

Se o panorama desportivo não nos agrada, então sonhemos outra realidade. Inspiremo-nos neste diálogo do escritor Mia Couto: 
Bento JO. Do desporto: Necessidade de recordar e avivar seu legado. Olimpianos - Journal of Olympic Studies. 2019; 3: 1-26.

- Dói-te alguma coisa?

- Dói-me a vida, doutor.

- E o que fazes, quando te assaltam essas dores?

- O melhor que sei fazer, excelência.

- E o que é?

- É sonhar ${ }^{\S}$.

Sim, os sonhos são insetos, sem corpo e sem ossos, que perfuram a resistência do mundo. Manifesta e obviamente, estão entranhados no ideário desportivo.

O desporto instala em preceitos e ideais, deveres e obrigações, ilusões e utopias. Implica metas e compromissos, hábitos e rotinas de trabalho. Coloca desafios e barreiras, e convida a nossa natureza a não se dar por satisfeita, a suplantar-se e a obter carta de alforria, procurando alcançar pódios de sublimação para os quais não se apresenta como particularmente predestinada.

Nele aprendemos que não podemos descansar e que o mérito e o sucesso sérios e honrados custam dedicação porfiada e suada, uma vez que o talento é raro, porquanto, ao contrário do que consta no registo bíblico, Deus não criou os humanos conformes à Sua imagem e semelhança; somente quando se distrai e bebe vários cálices do generoso vinho do Porto, em dia de aniversário, é que faz uma criatura à Sua medida.

O desporto é uma opção pela dificuldade, em face da tentação da facilidade. Socializa no trabalho em grupo e em equipa e leva a partilhar projetos com os demais. Civiliza a conduta em relação a nós e ao outro. Nele tentamos afastar-nos do gorduroso 'odor ao estábulo', que tanto incomodava Nietzsche, da animalidade que hoje não cessa de relinchar e escoucinhar à nossa volta.

No desporto continuaremos a levantar, lembra Fernando Savater, "o apreço por dons universalmente valiosos (habilidade, força, velocidade, elegância, jogo limpo...) e "a celebrar como própria a excelência onde quer que ela ocorra e seja quem for aquele que a demonstre". Haverá propósito mais edificante?!

Caros leitores:

Apetece-me gritar e erguer este pendão de Faiza Hayat, "O que me sustenta é a beleza (...) Rezo a tudo o que floresce e frutifica. Nada que cante ou que dance me é indiferente. Nada que fira ou destrua me é semelhante."

${ }^{\S}$ Esta diálogo foi tirado de uma postagem no Facebook, que não indicava a fonte original. 
Bento JO. Do desporto: Necessidade de recordar e avivar seu legado. Olimpianos - Journal of Olympic Studies. 2019; 3: 1-26.

Urge agendarmos, no discurso e na prática do desporto, o reencontro com os pilares da condição humana. Como professores e treinadores laboramos na construção desse templo de luz e razão, de grandeza ética e estética, erguido em cima da natureza. Professamos essa fé, porfiamos em imaginá-la e alargar os seus limites. Cuidamos da criação do corpo e da alma, do que somos por fora e temos por dentro, da forma humana interior e exterior, através da incorporação de arte.

O desporto é um edifício idealizado pela necessidade de beleza, pelo repto de superar a violência e a brutalidade, a grosseria e a torpeza na imagem que os humanos dão de si. Existe para encher de beleza a nossa vida, os nossos dias e condutas. É em nome dessa finalidade civilizacional que a sua prática se justifica. Porque as pessoas e o mundo têm fome de justiça, solidariedade, verticalidade e honradez, mas têm igualmente tanta ou maior fome de sensibilidade e beleza. De beleza nas palavras e reações, nos gestos e sentimentos, nos formalismos e cumprimentos, nos atos de olhar, sorrir e repartir. Da beleza de coexistir no nível máximo de autenticidade, verdade e Humanidade. E isto requer trabalho aturado e vigilância e controle ininterruptos.

No gesto desportivo, a estética integra a ética, refulge em trono cimeiro, confundem-se e contagiam-se o belus e o bonus. Bom gesto é o gesto bonito; e o gesto bonito tem que ser bom. A bondade está junta com a beleza e esta com a técnica, com o esforço para atingir o aprimoramento e o embelezamento das habilidades e prestações.

Eu vos reverencio, a todos quantos me acompanharam nesta viagem! De tudo quanto ficou dito, o mais valioso é a vida, elevada ao cume da exaltação e gratificação.

Desporto é vida! Vida preenchida e vivida com elevação, com lhaneza e hombridade. Com a beleza que tanto nos falta e tanta falta nos faz!

Pratiquemos esta ideia e exijamos que ela seja também praticada por todos quantos dirigem o desporto e se movem em torno dele. Será pedir-lhes demais um contributo para tornar o mundo mais belo e doce, para contornar a feiura e rudeza da animalidade e dar voz e encanto à Humanidade? 